\title{
Temporal Dynamics of Vegetative Cover and Surface Water Bodies in the Indus Delta, Pakistan
}

\author{
GHULAM SHABIR SOLANGI ${ }^{*}$, ALTAF ALI SIYAL ${ }^{* *}$, MUHAMMAD MUNIR BABAR ${ }^{* *}$, PIRAH SIYAL ${ }^{* * *}$
}

RECEIVED ON 09.10.2018 ACCEPTED ON 19.02.2019

\begin{abstract}
Under the current scenario of diminishing Indus River flows and changing the climate, the Indus Delta, the world's $5^{\text {th }}$ largest delta which has undergone rapid changes in water bodies and vegetative cover since last few decades, is under serious risk of losing its ecological functions. Assessing the temporal variation in vegetative cover and water bodies of the Indus Delta is essential for the future planning and ecosystem management in this region. The present study quantified the temporal patterns of the surface water bodies and vegetation cover, including crops, mangroves and other natural vegetation in the Indus Delta, by using field survey and remote sensing technique during the last 27 years. Results showed that the area covered by vegetation declined from $3002.35 \mathrm{~km}^{2}\left(22.98 \%\right.$ of the entire delta) to $2817.03 \mathrm{~km}^{2}$ (21.56\%) from 1990 to 2017, within which the area covered by mangrove forests declined from 1032.49 $\mathbf{k m}^{2}(7.90 \%)$ to $812.55 \mathrm{~km}^{2}(6.22 \%)$. However, the area of water bodies increased from $1611.67 \mathrm{~km}^{2}$ $(12.39 \%)$ to $3007.15 \mathrm{~km}^{2}(23.8 \%)$ in the same period. The reduction in freshwater flow to the delta, surface and subsurface seawater intrusion from the Arabian Sea and irrigation waters are the potential causes. The study would be helpful for policymakers to mitigate negative impacts and protect the ecosystem of the Indus Delta.
\end{abstract}

Key Words: Mangroves, Water Bodies, GIS, RS, Seawater intrusion

\section{INTRODUCTION}

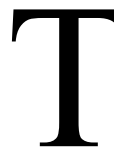
The surface of the earth is experiencing rapid changes in land-use/cover due to natural and anthropogenic activities [1]. Land use and land cover are two separate terms which are often used interchangeably [2-4]. The land cover defines the earth's physical features such as vegetation, water, soil, etc., while land use denotes to land utilized by the people for human activities [2]. Rapid growth in population, expansion in urbanization, advanced technologies are the drivers of land-use/cover changes around the globe [5]. Knowledge of accurate and updated information about the changing patterns of land-use/cover and natural resources is important for future planning and management [6].

Land-use/cover changes are one of the main causes of climate change through the modification of carbon, water,

Authors E-Mail: solangi_shabir@yahoo.com, aasiyal.uspcasw@faculty.muet.edu.pk,mmunirbabar.uspcasw@faculty.muet.edu.pk, pirahaltaf@chemist.com

* Department of Civil Engineering, Shaheed Zulfiqar Ali Bhutto Campus, MUET Khairpur Mir's

** U.S.-Pakistan Center for Advanced Studies in Water (USPCAS-W), Mehran University of Engineering and Technology, Jamshoro, Pakistan

*** National Centre of Excellence in Analytical Chemistry, Jamshoro, Pakistan

This is an open access article published by Mehran University Research Journal of Engineering and Technology, Jamshoro under the CC by 4.0 International License. 
and energy cycles [7]. As a result, agricultural lands, vegetative lands, forests, water bodies, as well as mineral resource lands are changing continuously throughout the globe [8]. At present, analysis for land-use/cover changes has become one of the major concerns for researchers, policy makers for sustaining and controlling environmental changes around the world [9]. Chatterjee and Razuiddin [10] reported that mapping the variations in ecological features is essential for proper planning, monitoring, and management of resources. Alphan [11], Muttitanon and Tripathy [12] also reported that information about changes in land-use/cover is necessary to update land cover maps for effective management and planning of the resources for sustainable development. The advanced development of the geographical information system (GIS) and remote sensing (RS) technologies help in the accurate measurement of such ecological resources [8]. Some studies $[8,13]$ have stated the usefulness of GIS and RS techniques in land-use/ cover change detection. Digital change detection techniques based on multi-temporal and multi-spectral remotely sensed data have demonstrated great potential for understanding landscape dynamics-detect, identify, map, and monitor differences in land-use/cover patterns over time, irrespective of the causal factors [14].

Due to climate change, arid and semi-arid areas of the world are under serious threat in the context of water scarcity and land degradation [15]. Pakistan is said to be one of the most vulnerable countries to climate change [16]. The literature reveals that during the current century, rainfall patterns, and river flows will be reduced, sea levels will rise all over the world [15]. The projected sea level rise of 180 to $590 \mathrm{~mm}$ will directly affect the Indus River Delta, which is the world's $5^{\text {th }}$ largest delta [17] with an active area of about 0.6 million hectares [18]. Due to dam construction and increasing water demand for irrigation and industry, the amount of freshwater flow into the Indus Delta significantly decreased [19-21]. As a result, saline water from the Arabian Sea is intruding into the delta at an alarming rate [20]. Many fertile lands have already degraded, fresh groundwater resources are converted into brackish water, and other adverse impacts are also vivid on vegetation, mangrove, water bodies and socioeconomic conditions of the people living in the Indus delta [19-20]. The mangrove forests are the backbone of the delta's ecosystem, providing a breeding ground and food for various species of fish and shrimps that are a key part of Pakistan's fisheries exports [20]. Besides this, mangrove performs as a defense line against storms, cyclones, and Tsunamis; contribute firewood and fodder for livestock; provide nourishing livelihood to local people living in the Indus Delta.

The area under the vegetation, mangroves forests, as well as water bodies, is continuously changing due to natural as well as anthropogenic activities. Studies on the changes in different land uses are important for forest monitoring and in overall environmental monitoring [22]. Thus, the present study was conducted to quantify the temporal dynamics of the vegetation, mangroves, and water bodies in the Indus Delta for the last 27 years (1990 to 2017). The outcomes of the study would be helpful for policymakers and planners to mitigate adverse impacts of seawater intrusion and climate change to save the ecosystem of the Indus Delta.

\section{MATERIALS AND METHODS}

\subsection{Description of the Indus River Delta}

The Indus River Delta stretches in southern districts viz. Thatta and Sujawal of the Sindh province of Pakistan (Fig. 1). According to Ramser Convention on Wetlands 1971 , Indus Delta is classified as the $5^{\text {th }}$ largest delta of the world [23], which comprises of seventeen major and numerous minor creeks. Among them, some of the major creeks are Chhan, Daboo, Danpora, Hajamro, Kajhar, Kanhar, Khai, Khober, Patiani, Phitti, Shahjee Wari,

Mehran University Research Journal of Engineering \& Technology, Volume 39, No. 1, January, 2020 [p-ISSN: 0254-7821, e-ISSN: 2413-7219] 
Turishan, Khuddi, Kharak, and Sir Creeks, etc. Agriculture and fishing are the main sources of earning for most of the local communities. The delta contains largest mangrove forests which provide shelter to many birds, as well as Indus Dolphin. The area receives on an average annual rainfall of about $220 \mathrm{~mm}$, whereas, the temperature in the area fluctuates between 23.8 to $28.7^{\circ} \mathrm{C}$ [24-32]. Due to the building of huge irrigation and hydropower networks in the Indus basin, the delta gets an inadequate amount of fresh water to maintain the ecosystem of the delta. As a result, the ecosystem of the delta is under serious threat. The area was once famous for its prosperity but now counted as one of the poorest areas of the country. The local people are migrating from their native places to safe areas in the search for shelter and food. Shortage of freshwater flow in the river and intrusion of saline water from the Arabian Sea into the delta are reported as the main causes of degradation of the delta.

\subsection{Data sources}

For assessment of the area under vegetation, mangroves, and surface water bodies, a geo-referenced field survey was carried out in the entire delta during 2016-2017 using the Garmin GPS MAP 62s system [33]. A study proforma was developed for recording the data. The proforma included information on geo-position (latitude and longitude coordinates), village/union council name, crop type, mangroves, and surface water bodies. The proforma was duly filled during the field visits. About 30 samples of each class such as vegetation, mangrove, and surface water bodies were recorded randomly.

For temporal analysis of water and vegetation, satellite imagery of Landsat-5, Landsat-7, and Landsat- 8 of the delta for 27 years from 1990 to 2017 (Table 1) was collected from the USGS (the United States Geological Survey) portal (http://glovis.usgs.gov).

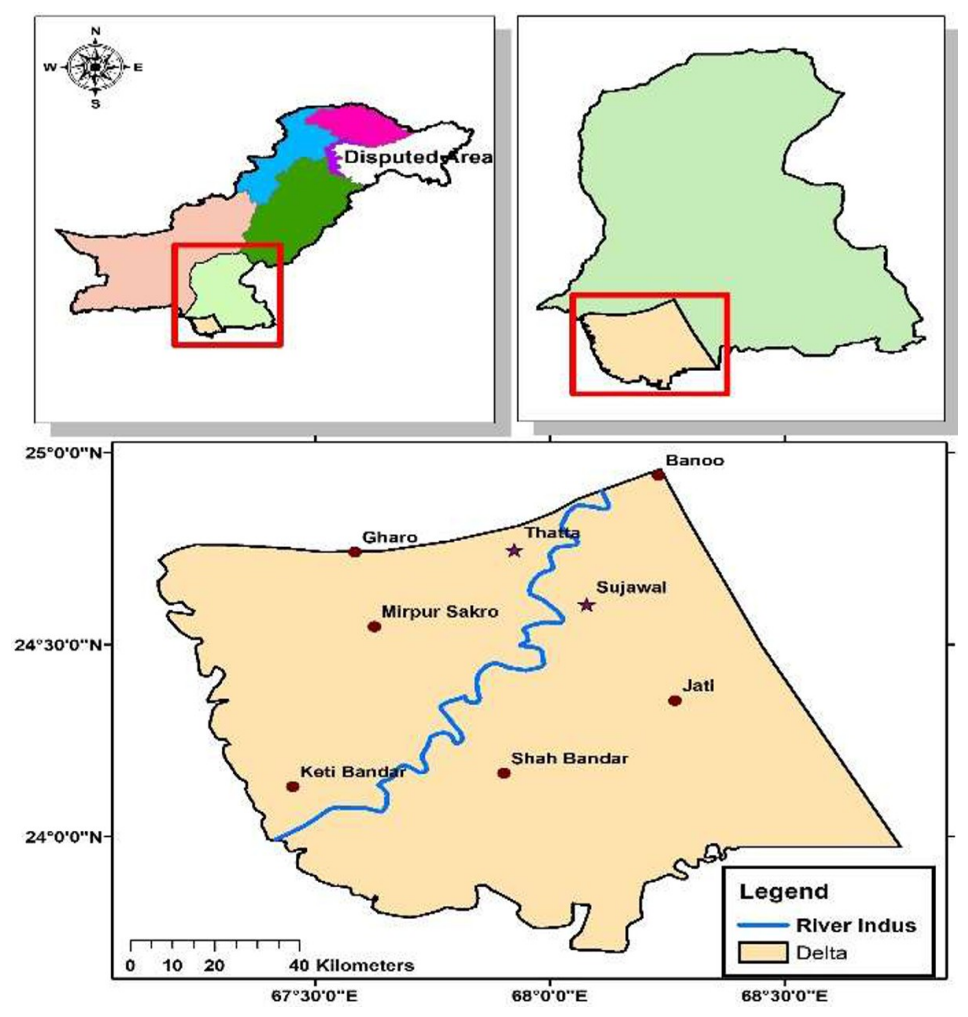

FIG. 1. LOCATION MAP OF THE INDUS DELTA 


\subsection{Vegetation and water indices}

Different vegetation and water indices viz., normalized difference vegetation, ratio vegetation, normalized difference water, normalized differential pond indices were used in the present study. These indices are briefly described in Table 2 .

\subsection{Extraction of Area of Interest (AOI) and Its Classification}

ArcGIS 10.3.1 software was used to process the acquired Landsat imagery of the delta. The "Extraction by Mask" tool was used to extract the study area (AOI) from the entire scene [36]. The AOI classified using maximum likelihood supervised and unsupervised classification. The area was thus trained for three classes'viz. vegetation, mangrove cover, and water bodies. The area under each created class was calculated by converting the raster data into polygons and then adding the area of all polygons of the same class [36]. However, the variation trends were determined using Pearson correlation analysis.

TABLE 1. LANDSAT SATELLITE IMAGERY USED IN THE STUDY

\begin{tabular}{|c|c|c|c|c|c|c|c|}
\hline S. No. & Year & Acquisition date & Path & Row & DOY & $d$ & $\theta \mathrm{s}$ \\
\hline 1 & \multirow{2}{*}{1990} & Feb., 10 & $151 \mathrm{a}$ & \multirow{2}{*}{43} & 41 & 0.98680 & 37.253531 \\
\hline 2 & & Feb., 17 & $152 \mathrm{a}$ & & 48 & 0.98814 & 38.963608 \\
\hline 3 & \multirow{2}{*}{1995} & Feb., 24 & $151 \mathrm{a}$ & \multirow{2}{*}{43} & 55 & 0.98959 & 39.025413 \\
\hline 4 & & Feb., 15 & $152 \mathrm{a}$ & & 46 & 0.98768 & 36.720616 \\
\hline 5 & \multirow{2}{*}{2000} & Feb., 14 & $151 \mathrm{~b}$ & \multirow{2}{*}{43} & 45 & 0.98755 & 43.035698 \\
\hline 6 & & Feb., 05 & $152 \mathrm{~b}$ & & 36 & 0.98596 & 40.742568 \\
\hline 7 & \multirow{2}{*}{2005} & Feb., 27 & $151 \mathrm{~b}$ & \multirow{2}{*}{43} & 58 & 0.99036 & 46.663667 \\
\hline 8 & & Feb., 18 & $152 b$ & & 49 & 0.98835 & 43.919991 \\
\hline 9 & \multirow{2}{*}{2010} & Feb., 09 & $151 \mathrm{~b}$ & \multirow{2}{*}{43} & 40 & 0.98662 & 41.729947 \\
\hline 10 & & Feb., 16 & $152 \mathrm{~b}$ & & 47 & 0.98794 & 43.632710 \\
\hline 11 & \multirow{2}{*}{2015} & Feb., 15 & $151 \mathrm{c}$ & \multirow{2}{*}{43} & 46 & 0.98774 & 44.574501 \\
\hline 12 & & Feb., 06 & $152 \mathrm{c}$ & & 37 & 0.98602 & 42.179202 \\
\hline 13 & \multirow{2}{*}{2017} & Feb., 20 & $151 \mathrm{c}$ & \multirow{2}{*}{43} & 51 & 0.98881 & 46.110403 \\
\hline 14 & & Feb., 11 & $152 \mathrm{c}$ & & 42 & 0.98698 & 43.506486 \\
\hline
\end{tabular}

TABLE 2. DESCRIPTION OF VEGETATION AND WATER INDICES

\begin{tabular}{|c|c|}
\hline Vegetation Indices & Water Indices \\
\hline $\begin{array}{c}\text { Normalized difference vegetation index } \\
\text { (NDVI) }=\text { Near Infrared-Red/Near Infrared }+ \text { Red } \\
\text { The index values usually vary between }+1 \text { to }-1 \text {. However, } \\
\text { a value of }+1 \text { represents a vegetated area, whereas }-1 \\
\text { represents the non-vegetated area. }\end{array}$ & 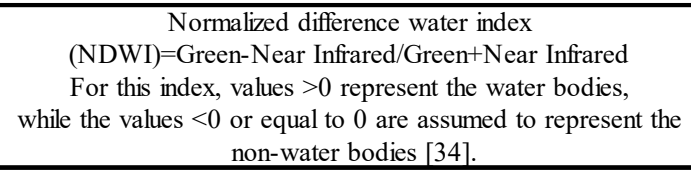 \\
\hline $\begin{array}{c}\text { Ratio Vegetative Index } \\
(\mathrm{RVI})=\mathrm{Red} / \mathrm{Near} \text { Infrared } \\
\text { The index values usually vary from zero to infinity, however, } \\
\text { values }<1.0 \text { represent a vegetated area, whereas }>1 \text {. } \\
0 \text { represent the non-vegetated area. }\end{array}$ & $\begin{array}{l}\text { Normalized differential pond index } \\
(\mathrm{NDPI})=\text { Shortwave Infrared-Green/Shortwave Infrared+Green } \\
\text { It is also used to estimate the area under water bodies [35]. }\end{array}$ \\
\hline
\end{tabular}

Mehran University Research Journal of Engineering \& Technology, Volume 39, No. 1, January, 2020 [p-ISSN: 0254-7821, e-ISSN: 2413-7219] 


\section{RESULTS AND DISCUSSION}

\subsection{Quantification of Temporal Variation in Vegetation cover}

Fig. 2 shows the vegetation masks of the Indus Delta for different years, i.e., from 1990 to 2017. Statistical summary of the temporal dynamics of the vegetation calculated using different geospatial techniques is described in Table 3. Analysis revealed that on average, about $3002.35 \mathrm{~km}^{2}(22.98 \%)$ area of the delta was covered with vegetation in 1990 . This declined to $2990.69 \mathrm{~km}^{2}$ $(22.89 \%)$ in 1995 , whereas, it increased to $4142.39 \mathrm{~km}^{2}$ $(31.7 \%)$ in $2000,4134.72 \mathrm{~km}^{2}(31.64 \%)$ in $2005,4701.29$ $\mathrm{km}^{2}(35.98 \%)$ in 2010 . This increment in vegetation from $3002.35 \mathrm{~km}^{2}$ (22.98\%) to $4701.29 \mathrm{~km}^{2}$ (35.98\%) during the last 20 years might be due to the plantation of several mangrove trees by the government, NGOs, Forest department [23]. No any specific trend of variation is observed. However, the mean area under vegetation declined to $2568.40 \mathrm{~km}^{2}(19.66 \%)$ in 2015 , and this area increased to $2817.03 \mathrm{~km}^{2}(21.56 \%)$ in the year 2017 . Changes in climate pattern have resulted in dramatic changes in the vegetation [17]. The change in vegetation is not only due to land degradation, but the increase in temperature is also affecting it significantly [23].

Overall the area of the delta under vegetation is slightly declined from $3002.35 \mathrm{~km}^{2}(22.98 \%)$ to $2817.03 \mathrm{~km}^{2}(21.56 \%)$ in the last 27 years, i.e., from 1990 to 2017 . Graphical representation of such variations in the delta is portrayed in Fig. 3.

The increase in vegetative cover in 2010 might be due to massive mangrove plantation on vast tidal floodplains by different NGOs, Forest Department, Government of Sindh, and Civil Society. Statistical analysis revealed no specific trend in the temporal variation of vegetation as it increased gradually from 1990 to 2010, but later it decreased significantly.

\subsection{Quantification of Temporal Variation in Mangroves}

Table 4 shows the temporal variation in the area under mangroves quantified through supervised, unsupervised techniques and vegetation indices from 1990 to 2017. Graphical representation of such temporal change is shown in Fig. 4. It showed that on average about 1032.49.5 $\mathrm{km}^{2}(7.90 \%)$ area of the delta was covered with mangrove forests in 1990. However, it decreased to $631.6 \mathrm{~km}^{2}$ or
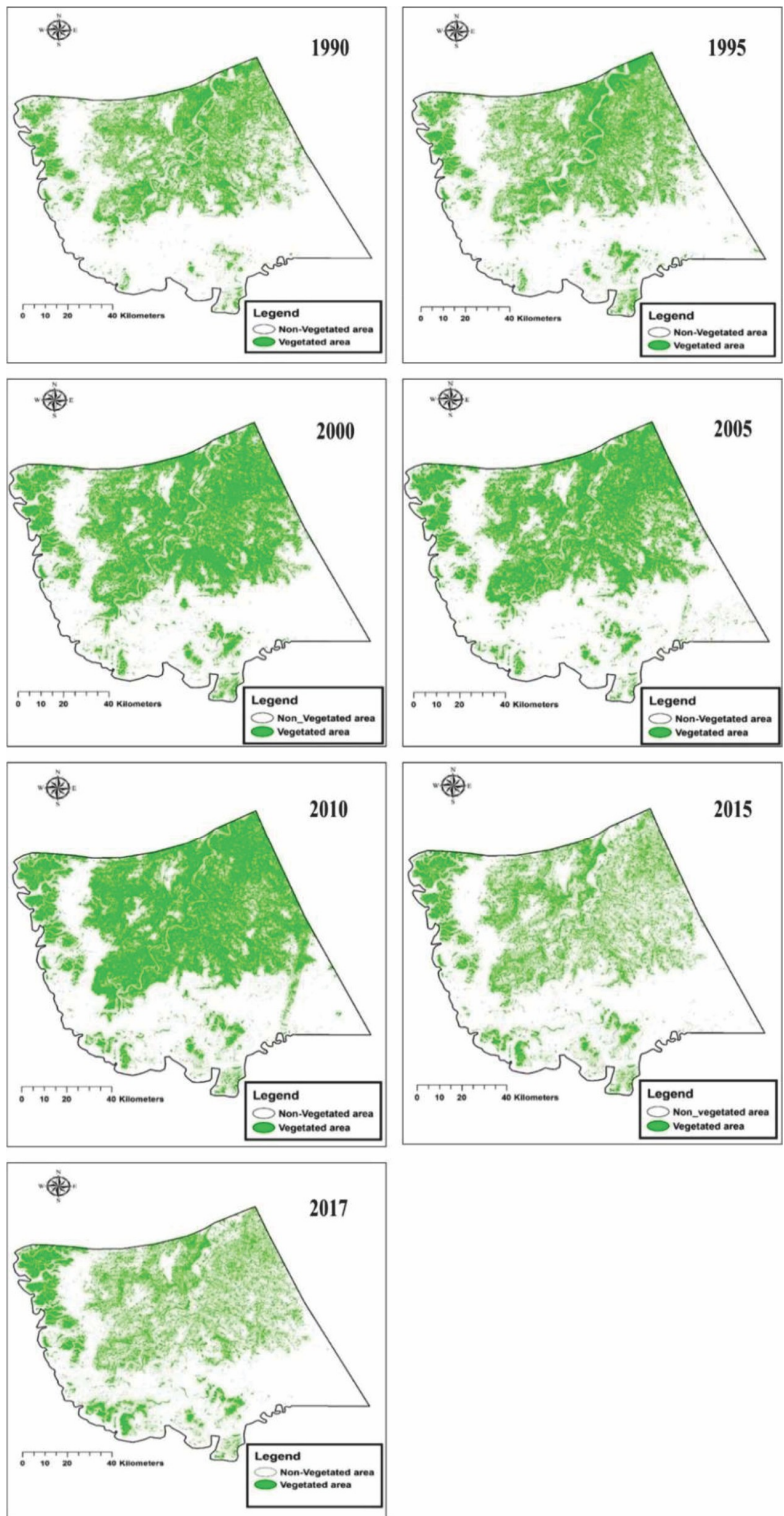

FIG. 2. VEGETATION MASKS OF THE INDUS DELTA FOR DIFFERENT YEARS (1990-2017)

Mehran University Research Journal of Engineering \& Technology, Volume 39, No. 1, January, 2020 [p-ISSN: 0254-7821, e-ISSN: 2413-7219] 
$4.83 \%$ of the total geographical area of the delta in 2005 . Then it increased to $812.55 \mathrm{~km}^{2}(6.22 \%)$ in 2017 . The increase in mangrove forests cover in 2010 and 2015 might be due to massive mangrove plantation on vast tidal plains by NGOs, Forest Department, Government of Sindh, and

Civil Society in 2009 and 2013 [23,37].

TABLE 3. STATISTICAL SUMMARY OF THE TEMPORAL VARIATION IN THE VEGETATION OF THE INDUS DELTA (1990-2017)

\begin{tabular}{|c|c|c|c|c|c|c|c|c|c|}
\hline \multirow[t]{2}{*}{ Year } & \begin{tabular}{|l}
$\begin{array}{l}\text { Unsupervised } \\
\text { classification }\end{array}$ \\
\end{tabular} & $\begin{array}{c}\text { Supervised } \\
\text { classification }\end{array}$ & NDVI & RVI & Mean & \multirow[t]{2}{*}{$\%$} & \multirow{2}{*}{ STD* } & \multirow[t]{2}{*}{$\mathrm{SE}^{*}$} & \multirow[t]{2}{*}{$\mathrm{CI}^{*}$} \\
\hline & $\mathrm{km}^{2}$ & $\mathrm{~km}^{2}$ & $\mathrm{~km}^{2}$ & $\mathrm{~km}^{2}$ & $\mathrm{~km}^{2}$ & & & & \\
\hline 1990 & 3104.46 & 2850.41 & 3053.54 & 3000.98 & 3002.348 & 22.98 & 402.11 & 201.05 & 394.056 \\
\hline 1995 & 2884.46 & 2941.34 & 3147.65 & 2989.3 & 2990.688 & 22.89 & 194.23 & 97.11 & 190.339 \\
\hline 2000 & 4113.75 & 4056.13 & 4258.93 & 4140.74 & 4142.388 & 31.70 & 191.19 & 95.6 & 187.366 \\
\hline 2005 & 4107.76 & 3986.01 & 4293.44 & 4151.66 & 4134.718 & 31.64 & 173.8 & 86.9 & 170.323 \\
\hline 2010 & 4585.68 & 4717.09 & 4801.36 & 4701.02 & 4701.288 & 35.98 & 130.24 & 65.12 & 127.632 \\
\hline 2015 & 2604.7 & 2509.72 & 2590.07 & 2569.09 & 2568.395 & 19.66 & 72.9 & 36.45 & 71.439 \\
\hline 2017 & 2885.06 & 2648.94 & 2823.54 & 2910.57 & 2817.028 & 21.56 & 229.39 & 114.7 & 224.801 \\
\hline
\end{tabular}

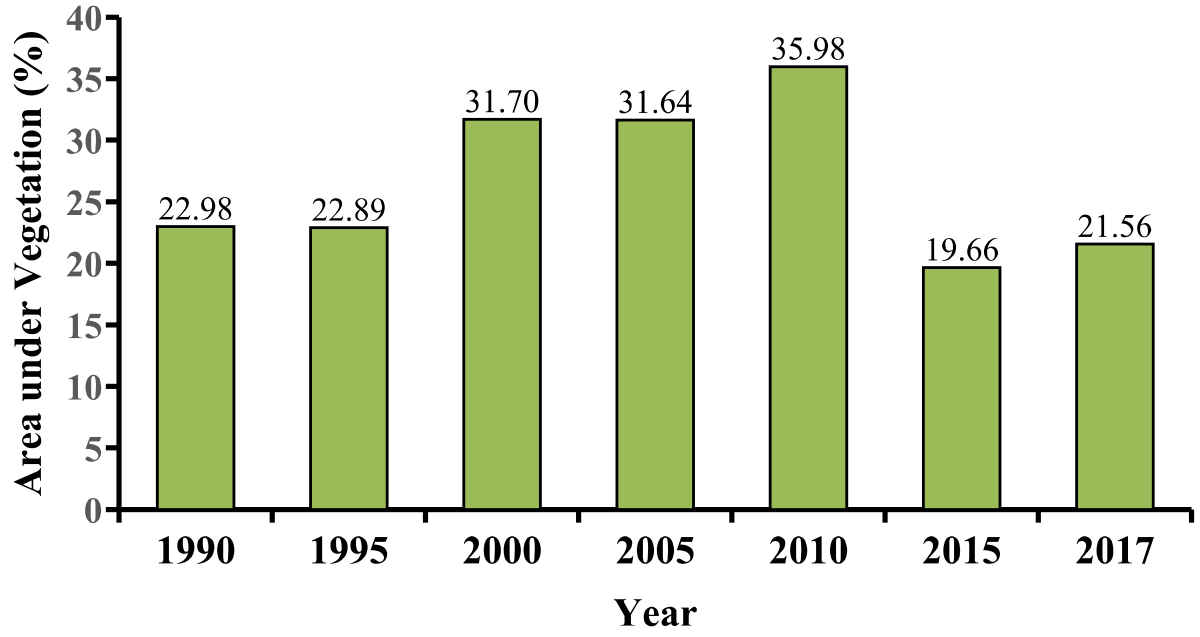

FIG. 3. GRAPHICAL REPRESENTATION OF TEMPORAL DYNAMICS OF VEGETATION IN THE INDUS DELTA

TABLE 4. STATISTICAL SUMMARY OF THE TEMPORAL DYNAMICS OF MANGROVES IN THE INDUS DELTA (1990-2017)

\begin{tabular}{|c|c|c|c|c|c|c|c|c|c|c|}
\hline \multirow{2}{*}{ Year } & \multicolumn{2}{|c|}{ Unsupervised classification } & \multicolumn{2}{|c|}{ Supervised classification } & \multicolumn{2}{|c|}{ NDVI } & \multicolumn{2}{|c|}{ RVI } & \multirow{2}{*}{$\begin{array}{l}\text { Mean area } \\
\quad\left(\mathrm{km}^{2}\right)\end{array}$} & \multirow{2}{*}{$\begin{array}{c}\% \\
\text { of the } \\
\text { delta }\end{array}$} \\
\hline & $\mathrm{km}^{2}$ & $\%$ & $\mathrm{~km}^{2}$ & $\%$ & $\mathrm{~km}^{2}$ & $\%$ & $\mathrm{~km}^{2}$ & $\%$ & & \\
\hline 1990 & 1081.73 & 8.28 & 978.538 & 7.49 & 1003.5 & 7.68 & 1066.18 & 8.16 & 1032.49 & 7.90 \\
\hline 1995 & 793.24 & 6.07 & 756.248 & 5.79 & 776.4 & 5.94 & 729.072 & 5.58 & 763.74 & 5.84 \\
\hline 2000 & 745.34 & 5.70 & 741.294 & 5.67 & 751.6 & 5.75 & 727.386 & 5.57 & 741.40 & 5.67 \\
\hline 2005 & 597.54 & 4.57 & 636.164 & 4.87 & 647.5 & 4.96 & 645.234 & 4.94 & 631.61 & 4.83 \\
\hline 2010 & 915.22 & 7.00 & 951.323 & 7.28 & 911.3 & 6.97 & 865.234 & 6.62 & 910.77 & 6.97 \\
\hline 2015 & 904.14 & 6.92 & 853.241 & 6.53 & 977.2 & 7.48 & 678.977 & 5.20 & 853.39 & 6.53 \\
\hline 2017 & 882.21 & 6.75 & 803.173 & 6.15 & 821.1 & 6.28 & 743.73 & 5.69 & 812.55 & 6.22 \\
\hline
\end{tabular}

Mehran University Research Journal of Engineering \& Technology, Volume 39, No. 1, January, 2020 [p-ISSN: 0254-7821, e-ISSN: 2413-7219] 
Likewise, vegetative cover, no specific trend in the temporal variation of mangroves was observed as it decreased gradually from 1990 to 2005 , but later it increased significantly.

\subsection{Quantification of Temporal Variation in the Area under Surface Water Bodies}

Various methods such as supervised, unsupervised classifications, water indices as described earlier were used to quantify the temporal variation in the area under water bodies during the last 27 years. Fig. 5 shows the water bodies masks of the Indus Delta for different years, i.e., from 1990 to 2017.

The statistical data matrix of temporal dynamics of water bodies is summarized in Table 5, while its graphical representation is portrayed in Fig. 6. The figure showed that on an average about $1611.67 \mathrm{~km}^{2}(12.39 \%)$ area of the delta was under water bodies in 1990. This increased to $2104.08 \mathrm{~km}^{2}(16.51 \%)$ in 1995 , and to $3007.15 \mathrm{~km}^{2}(23.8 \%)$ in 2017. The increase in area under water almost doubled in the last 27 years. This might be because of the entry of saline water from the Arabian Sea due to the reduction of freshwater flow from the Indus River in the deltaic area. Alamgir et al. [17] also reported that seawater is enhanced in the Indus delta due to the reduced flow in river Indus that is affecting the deltaic system.
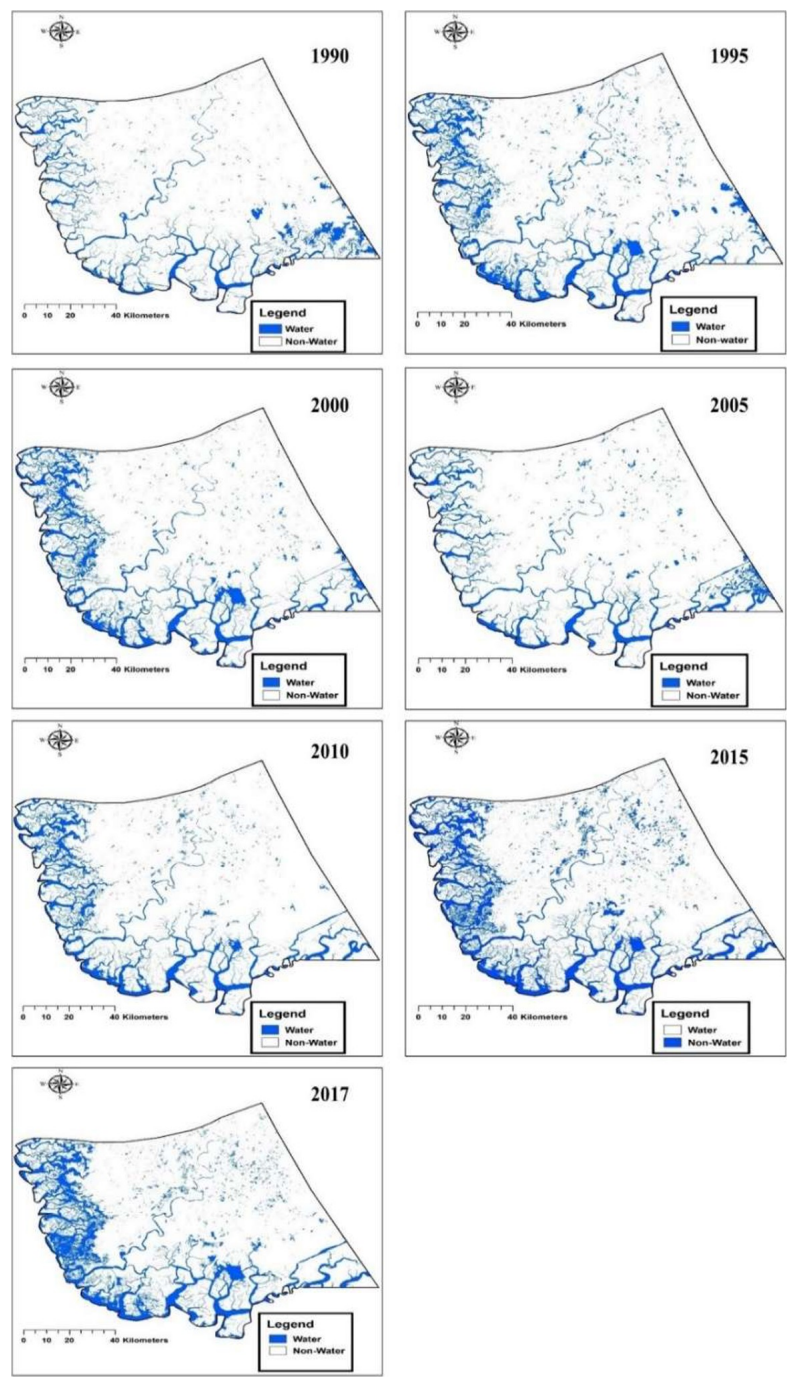

FIG. 5. WATER MASKS OF THE INDUS DELTA FROM 1990-2017

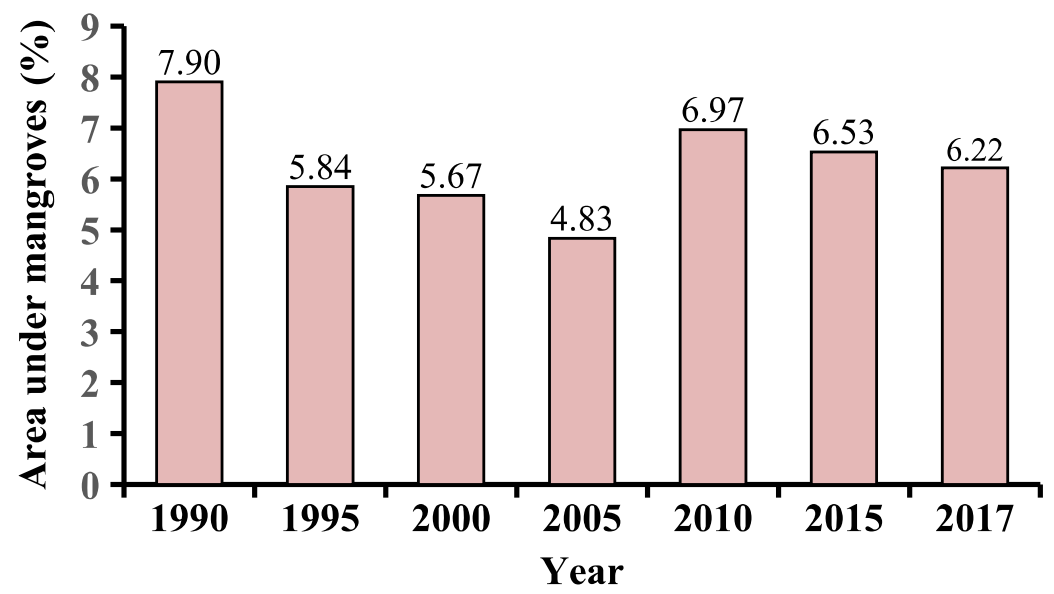

FIG. 4.GRAPHICAL REPRESENTATION OF TEMPORAL DYNAMICS OF MANGROVES IN THE INDUS DELTA

Mehran University Research Journal of Engineering \& Technology, Volume 39, No. 1, January, 2020 [p-ISSN: 0254-7821, e-ISSN: 2413-7219] 
Statistical analysis revealed a significant trend in temporal variation of surface water bodies in the Indus delta during the last 27 years, i.e., 1990 to 2017 with a coefficient of determination $\left(R^{2}=0.65\right)$.

\subsection{Implications of the changes in vegetation and seawter intrusion}

Due to seawater intrusion, and variation in the vegetation, mangroves, and surface water bodies in the Indus delta, shoreline erosion is increased, many fertile lands are degraded, the area under vegetative cover as well the production/yield is decreased significantly. That has ultimately affected the ecosystem and livelihood of the people living in the delta. Several families have migrated from their ancestral towns to the safe places of surrounded cities/towns in search of food and shelter. Mahar [38] also reported that due to seawater intrusion into the Indus delta, people are evacuating the populated areas, per acreage crop yield of agricultural lands is decreasing continuously, and socio-economic conditions of the people living in the deltaic areas are badly affected.

TABLE 5. STATISTICAL SUMMARY OF TEMPORAL DYNAMICS OF WATER BODIES IN THE INDUS DELTA

\begin{tabular}{|c|c|c|c|c|c|c|c|c|c|c|}
\hline \multirow{2}{*}{ Year } & $\begin{array}{c}\text { Unsupervised } \\
\text { Classification }\end{array}$ & $\begin{array}{c}\text { Supervised } \\
\text { Classification }\end{array}$ & Single & NDWI & NDPI & Mean & \multirow{2}{*}{$\%$} & \multirow{2}{*}{ STD } & SE & CI \\
\hline 1990 & 1531.94 & 1431.13 & 1839.84 & 1636.64 & 1618.78 & 1611.67 & 12.39 & 151.40 & 67.71 & 132.71 \\
\hline 1995 & 2435.93 & 1700.68 & 2388.99 & 1837.85 & 2156.93 & 2104.08 & 16.51 & 326.99 & 146.24 & 286.62 \\
\hline 2000 & 1965.96 & 1688.95 & 2102.87 & 1761.36 & 2134.68 & 1930.76 & 16.34 & 199.76 & 89.33 & 175.09 \\
\hline 2005 & 2031.29 & 1827.87 & 1970.77 & 1864.92 & 1858.37 & 1910.64 & 14.22 & 86.38 & 38.63 & 75.71 \\
\hline 2010 & 1713.62 & 1573.66 & 1962.34 & 1651.40 & 1955.39 & 1771.28 & 14.96 & 178.29 & 79.73 & 156.28 \\
\hline 2015 & 2934.66 & 2634.83 & 2688.32 & 2735.59 & 2729.69 & 2744.62 & 20.89 & 113.62 & 50.81 & 99.59 \\
\hline 2017 & 3049.79 & 2851.76 & 3025.92 & 2988.39 & 3119.90 & 3007.15 & 23.88 & 99.23 & 44.37 & 86.97 \\
\hline
\end{tabular}

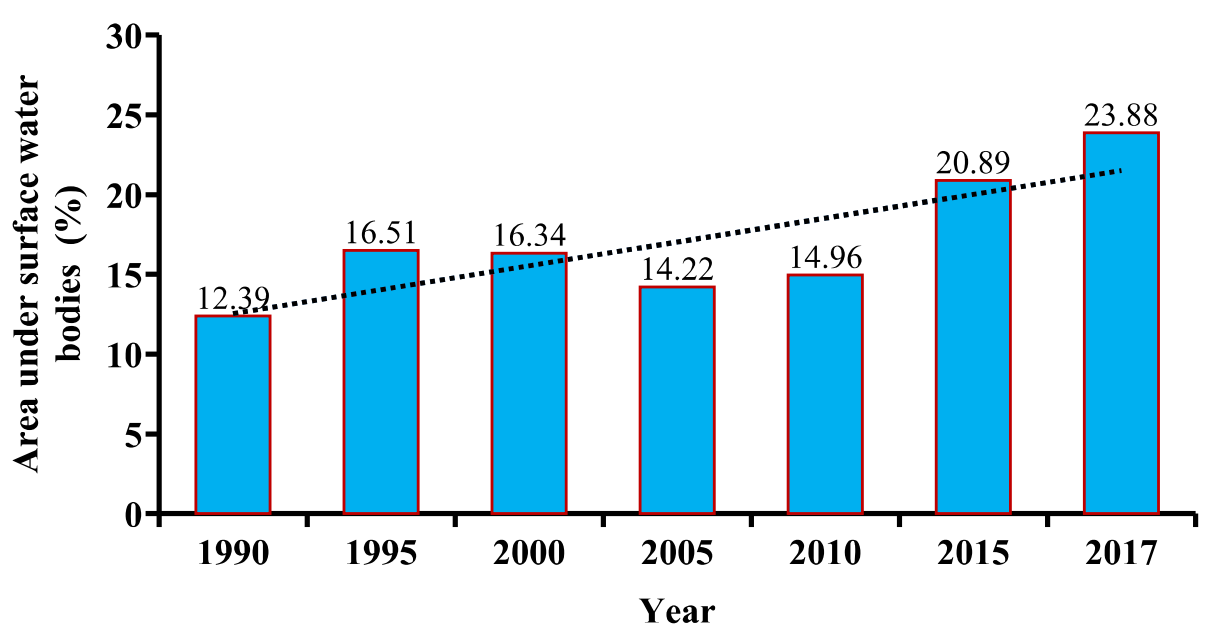

FIG. 6. GRAPHICAL REPRESENTATION OF TEMPORAL DYNAMICS OF WATER BODIES IN THE INDUS DELTA 


\subsection{River flow below Kotri Barrage}

The analysis of the data of annual flow below Kotri Barrage (last barrage on the river Indus) from 1937 to 2016 revealed that there was a linear decrease in flow especially after commissioning of Tarbela dam in 1976 such that there is a decrease of $80 \%$ in the flow. The decrease in Indus River flow in BCM (billion cubic meters) below Kotri Barrage with time is shown in Fig. 7.

The number of days with no flow below Kotri barrage have also drastically increased after 1970 such that the flow is not continuous throughout the year. The river flow below Kotri Barrage is now confined within a period of about 60 days of monsoon only as shown in Fig. 8.

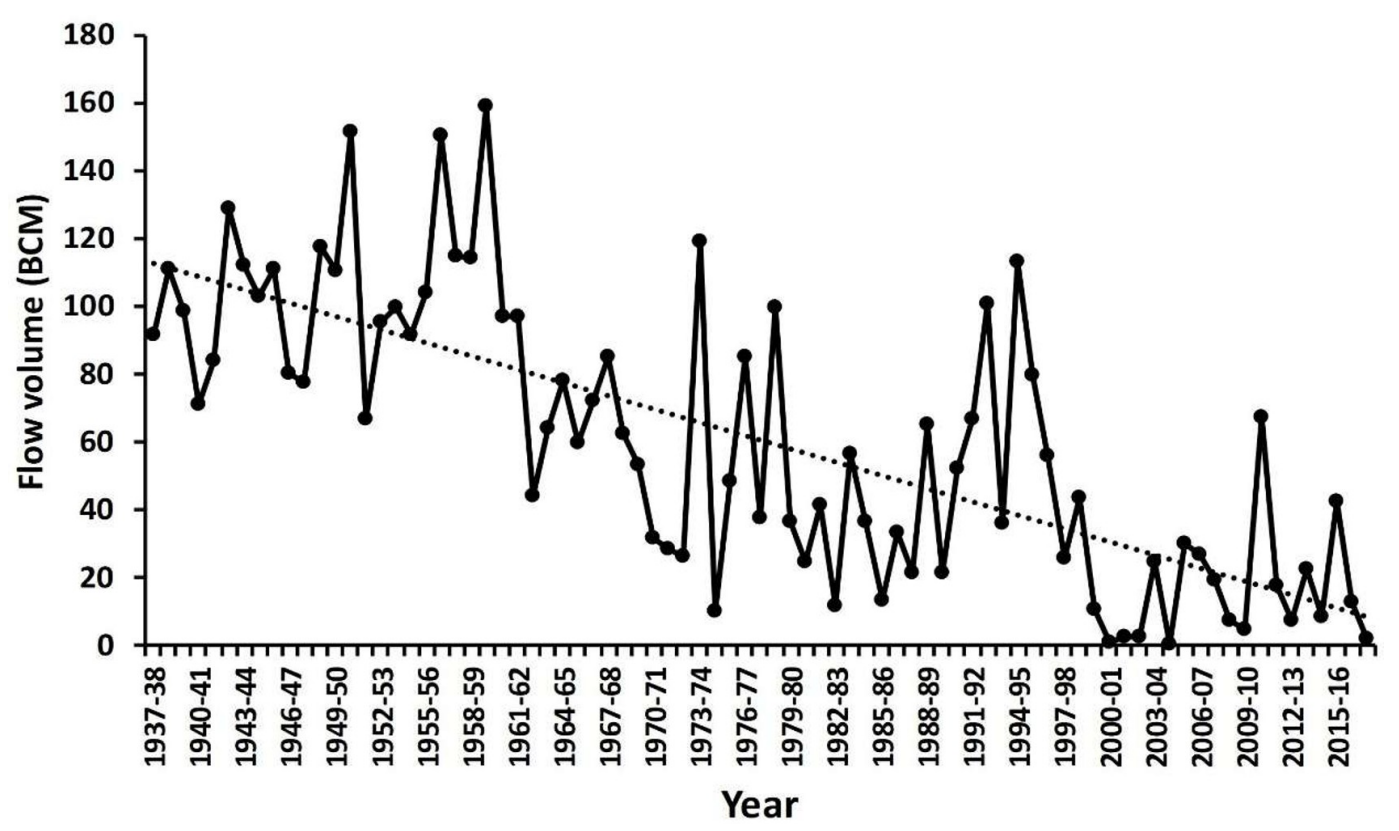

FIG. 7. THE DECREASE IN INDUS RIVER FLOW BELOW KOTRI BARRAGE WITH TIME

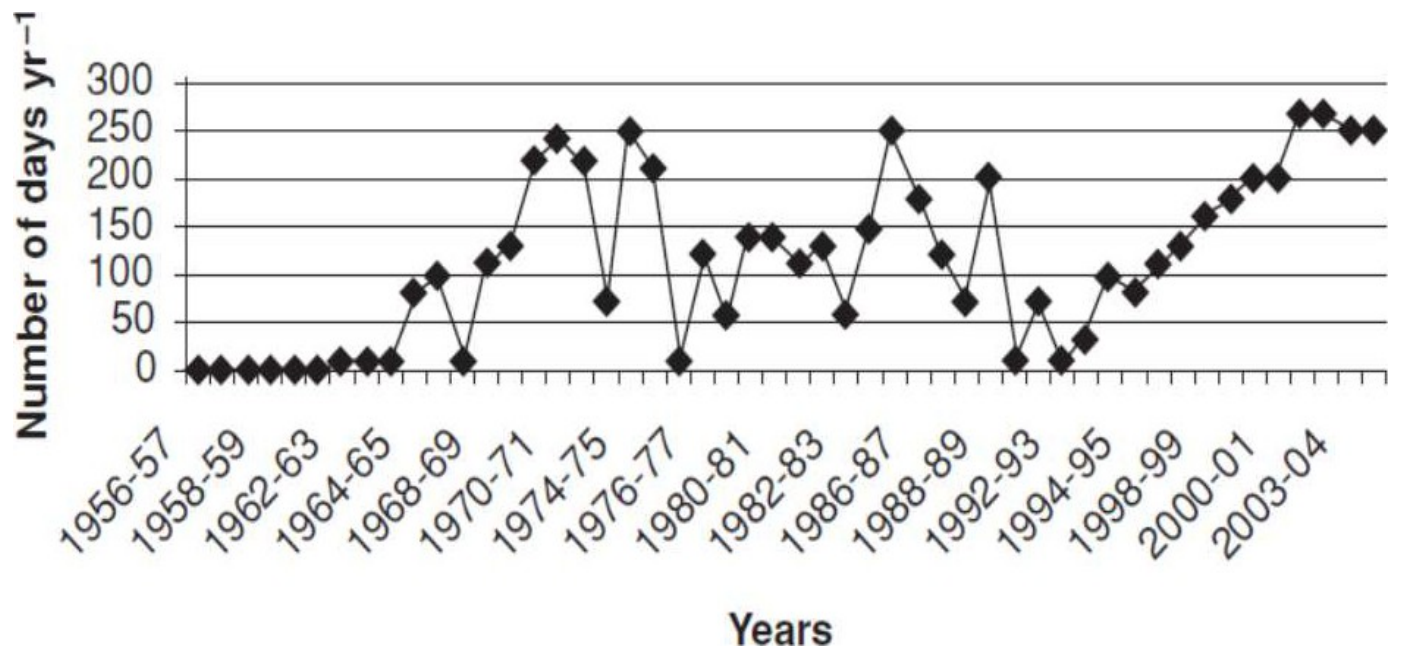

FIG. 8. ZERO FLOW DAYS BELOW KOTRI BARRAGE DOWNSTREAM (SOURCE: INAM ET AL. [39]) 


\section{CONCLUSIONS}

In the present study, field and satellite data were used to quantify the temporal variations in the vegetation, mangroves and water bodies in the Indus Delta for the period of the last 27 years (1990-2017). Various algorithms and indices such as supervised, unsupervised classifications, vegetation, and water indices were used to detect any temporal change in the natural features in the Indus Delta. Analysis revealed that the area under vegetation is declined from $3002.35 \mathrm{~km}^{2}(22.98 \%)$ in 1990 to $2817.03 \mathrm{~km}^{2}(21.56 \%)$ in 2017 . Temporal variations in the mangrove forests also showed that on average, the area under mangrove forests is declined from $1032.5 \mathrm{~km}^{2}$ $(7.90 \%)$ in 1990 to $812.55 \mathrm{~km}^{2}(6.22 \%)$ in 2017 . However, the study revealed that on average, the area under water bodies is increased from $1611.67 \mathrm{~km}^{2}(12.39 \%)$ in 1990 to $3007.15 \mathrm{~km}^{2}(23.8 \%)$ in 2017 . This huge increase in water bodies has become almost doubled in the last 27 years. This may be due to the entry of Arabian Sea water due to the reduction of freshwater flow in the Indus River for its delta. The present study will be helpful for the sustainable development of livelihoods of poor communities where women have a major share/role and will have an impact on the social life of rural women of the Indus Delta.

\section{ACKNOWLEDGEMENT}

We are highly thankful to the U.S.-Pakistan Center for Advanced Studies in Water, Mehran University of Engineering and Technology, Jamshoro for funding the project "Climate Change: Assessing Impact of Seawater Intrusion on Soil, Water and Environment in the Indus Delta using GIS and RS tools." The project was funded under the Applied Research Policy of the center. The United States Geological Survey is also highly acknowledged for providing multi-temporal satellite imagery for the study.

\section{REFERENCES}

[1] Cheruto, M.C., Kauti, M.K., Kisangau, P.D., and Kariuki, P., "Assessment of Land Use and Land Cover Change Using GIS and Remote Sensing Techniques: A Case Study of Makueni County, Kenya”, Journal of Remote Sensing \& GIS, Volume 5, pp. 175, 2016.

[2] Rawat, J.S., and Kumar, M., "Monitoring land use/cover change using remote sensing and GIS techniques: a case study of Hawalbagh block, district Almora, Uttarakhand, India", The Egyptian Journal of Remote Sensing and Space Science, Volume 18, No. 1, pp. 77-84, 2015

Butt, A., Shabbir, R., Ahmad, S.S., and Aziz, N., "Land use change mapping and analysis using remote sensing and GIS: a case study of Simly watershed, Islamabad, Pakistan", Egyptian Journal of Remote Sensing and Space Science, Volume 18, No. 2, pp. 251-259, 2015.

Hua, A.K., "Land Use Land Cover Changes in Detection of Water Quality: A Study based on Remote Sensing and Multivariate Statistic" Journal of Environmental and Public Health, Volume 2017, pp. 1-12, 2017

Barros, J.X., "Urban growth in Latin American cities: exploring urban dynamics through agent-based simulation", Doctoral Thesis, University of London, London, 2004.

[6] Ayele, G.T., Tebeje, A.K., Demissie, S.S., Belete, M.A., Jemberrie, M.A., Teshome, W.M., Mengistu, D.T., and Teshale, E.Z., “Time Series Land Cover Mapping and Change Detection Analysis Using Geographic Information System and Remote Sensing, Northern Ethiopia”, Air, Soil and Water Research, Volume 11, pp. 1-18, 2018.

[7] Mas, J.F., Lemoine-Rodriguez, R., Gonzalez-Lopez, R., Lopez-Sanchez, J., Pina-Garduno, A., and Herrera-Flores, E., "Land use/land cover change detection combining automatic processing and visual interpretation", European Journal of Remote Sensing, Volume 50, No. 1, pp. 626-635, 2017. 
[8] Arulbalaji, P., and Gurugnanam, B., "Geospatial Science for 16 Years of Variation in Land Use/Land Cover Practice Assessment around Salem District, South India", Journal of Geosciences and Geomatics, Vol. 2, No. 1, pp. 17-20, 2014.

Farid, K., Vijayalakshmi, T., and Santhosh, K., "Land use land cover change detection of Ghatkesar mandal, Ranga Reddy district using remote sensing and GIS", International Journal of Scientific and Engineering Research, Volume 3, No. 11, 2012

[10] Chatterjee, C., and Razuiddin, M., "Determination of Water Quality Index (WQI) of a degraded river in Asansol Industrial Area, Raniganji, Burdwan, West Bengal", Nature Environment and Pollution Technology, Volume 1, pp.181-189, 2002.

Muttittanon, W., Tripathi, N.K., "Land use/cover changes in the coastal zone of Bay Don Bay, Thailand using Landsat 5 TM data", International Journal of Remote Sensing, Volume 26, Issue 1, pp. 2311-2323, 2005 .

[13] Jaiswal, R.K., Saxena, R., and Mukherjee, S., "Application of Remote Sensing Technology for Landuse / Landcover change analysis", J. Indian Soc. Remote Sensing, Volume 27, No. 2, pp 123-128, 1999.

[14] Coppin, P., I. Jonckheere, I., Nackaerts, K., Muys, B., "Digital Change Detection Methods in Ecosystem Monitoring: A Review", International Journal of Remote Sensing, Volume 25, No. 9, pp. 1565-1596, 2004.

[15] IPCC., "Climate Change and Water, Inter-governmental Panel on Climate Change”, Technical Report IV, 2008.

[16] Rasul, G., Mahmood, A., Sadiq, A., and Khan, S.I., "Vulnerability of the Indus Delta to Climate Change in Pakistan", Pakistan Journal of Meteorology, Volume 8, No. 16, pp. 89-107, 2012.
[17] Alamgir, A., Khan, M.A., Shaukat, S.S., Kazmi, S.J, Qureshi, S., and Khanum F., Appraisal of Climate Change Impacts on the Coastal Areas of Sindh Using Remote Sensing Techniques", American-Eurasian J. Agric. \& Environ. Sci., Volume 15, No. 6, pp. 1102-1112, 2015.

[18] Meynell, P., and Qureshi, T., "Sustainable management of mangroves in the Indus Delta, Pakistan", In Towards the Wise Use of Wetlands, David TJ (ed.). Ramsar Bureau: Gland; 113-22, 1993.

[19] Laghari, A.N., Abbasi, H.U., Aziz, A., and Kanasro, N.A., "Impact Analyses of Upstream Water Infrastructure Development Schemes on Downstream Flow, Sediment Discharge and Subsequent Effect on Deltaic Region, SURJ, Volume 47, No. 4, pp. 805-808, 2015.

[20] Thomas, M., "The slow and dangerous death of Pakistan's Indus River Delta”, 2015.http://qz.com/ $448049 /$ the - s low - and - dangerous - de a th - o fHYPERLINK "http://qz.com/448049/the-slow-anddangerous-death-of-pakistans-indus-riverdelta"pakistans HYPERLINK "http://qz.com/448049/ the-slow-and-dangerous-death-of-pakistans-indus-riverdelta"-Indus-river-delta.Visited on Aug. 22, 2016.

[21] Chandio, N.H., Anwar, M.M., and Mallah, Q.H., "Impacts of Climate Change on Coast Line of Arabian Sea: A Case Study of Indus River Delta, Pakistan", Sindh Univ. Res. Jour. (Sci. Ser.), Volume 50, No. 1, pp. 147-152, 2018.

[22] Islam, K., Jashimuddin, M., Nath, B., and Nath, T.K., "Land use classification and change detection by using multi-temporal remotely sensed imagery: The case of Chunati wildlife sanctuary, Bangladesh”, The Egyptian Journal of Remote Sensing and Space Sciences, Volume 21, pp. 37-47, 2018.

[23] Rehman, Z., Kazmi, S.J.H., Khanum, F., and Samoon, Z.A., "Analysis of Land Surface Temperature and NDVI Using Geo-Spatial Technique: A Case study of Keti Bundar, Sindh, Pakistan", Journal of Basic and Applied Sciences, Volume 11, pp. 514-527, 2015.

[24] Kalhoro, N.A., He, Z., Xu, D., Faiz, M., Yafei, L.V., Sohoo, N., and Bhutto, A.H., "Vulnerability of the Indus River Delta of the North Arabian Sea, Pakistan", Global NEST J., Volume 18, pp. 599-610, 2016.23 
[25] Solangi, G.S., Siyal, A.A., Babar, M.M., and Siyal, P., "Groundwater quality mapping using geographic information system: a case study of District Thatta, Sindh", Mehran University Research Journal of Engineering and Technology, Volume 36, No. 4, pp. 1059-1072, 2017.

[26] Solangi, G.S., Siyal, A.A., Babar, M.M., and Siyal, P., "Evaluation of surface water quality using the water quality index (WQI) and the synthetic pollution index (SPI): a case study of Indus Delta region of Pakistan", Desalination and Water Treatment., Volume 118, pp. 39-48, 2018.

[27] Solangi, G.S., Siyal, A.A., Babar, M.M., and Siyal, P., "Groundwater Quality Evaluation using the Water Quality Index (WQI), the Synthetic Pollution Index (SPI) and Geospatial tools: a case study of Sujawal District, Pakistan", Human and Ecological Risk Assessment: An International Journal, 2019a. https://doi.org/10.1080/ 10807039.2019 .1588099

Solangi, G.S., Siyal, A.A., Babar, M.M., and Siyal, P., "Application of water quality index, synthetic pollution index, and geospatial tools for the assessment of drinking water quality in the Indus Delta, Pakistan", Environmental Monitoring and Assessment, 2019b. https://doi.org/10.1007/s10661-019-7861-x

[29] Solangi, G.S., Siyal, A.A., Babar, M.M., Siyal, P., "Evaluation of Drinking water quality using the Water Quality Index (WQI), the Synthetic Pollution Index (SPI) and Geospatial tools in Thatta District, Pakistan", Desalination and Water Treatment Journal, Volume 160, pp. 202-213, 2019c. doi: 10.5004/dwt.2019.24241

[30] Solangi, G.S., Siyal, A.A., Siyal, P., "Spatiotemporal Dynamics of Land Surface Temperature and its impact on the Vegetation", Civil Engineering Journal, Volume 5, No. 8, pp. 1753-1763, 2019d.

[31] Solangi, G.S., Siyal, A.A., Babar, M.M., Siyal, P., "Spatial Analysis of Soil Salinity in the Indus River Delta, Pakistan”, Engineering, Technology and Applied Science Research, Vol. 9, Issue 3, pp. 4271-4275, 2019e.
[32] Solangi, G.S., Siyal, A.A., Siyal, P., "Analysis of Indus Delta Groundwater and Surface water Suitability for Domestic and Irrigation Purposes", Civil Engineering Journal, Volume 5, Issue 7, pp. 1599-1608, $2019 \mathrm{f}$.

[33] Siyal, A.A., Lakhair, I., Babar, M.M., Siyal, P., Solangi, G.S., "Study of Soil, Water, and Cropping Pattern in Danastar Wah (Manchar Lake) Command Area Using Geospatial Tools", Volume 37, No. 4, 655-668, 2018.

[34] McFeeters, S.K., "Using the Normalized Difference Water Index (NDWI) within a Geographic Information System to Detect Swimming Pools for Mosquito Abatement: A Practical Approach", Remote Sens., Volume 5, pp. 3544-3561, 2013.

[35] Lacaux, J.P., Tourre, Y.M., Vignolles, C., Ndione, J.A., and Lafaye, M., "Classification of ponds from highspatial resolution remote sensing: Application to Rift Valley Fever epidemics in Senegal", Remote Sens Environ., Volume 106, pp.66-74, 2006.

[36] Siyal, A.A., Siyal, A.G., and Mahar, R.B., "Spatial and temporal dynamics of Pai forest vegetation in Pakistan assessed by RS and GIS”, Journal of Forestry Research, Volume 28, No. 3, pp. 593-603, 2016.

[37] Daily Times., "Sindh government sets to make a record of mangrove plantation”, 2018. https:// dailytimes.com.pk/179993/sindh-government-setsmake-record-mangrove-plantation-february-15/ (visited on April 5, 2018).

[38] Mahar, G.A., "Geomorphic Degradation of Indus Delta and Its Demographic Impact", Doctoral dissertation, University of Karachi, Karachi, 2010.

[39] Inam, A., Khan, A.T.M., Amjad, S., Danish, M. and Tabrez, A.R., "Natural and manmade stresses on the stability of Indus deltaic eco-region", Extended Abstract, $5^{\text {th }}$ International Conference on Asian Marine Geology, Bangkok, 2004. Thailand (IGCP475/APN). 